\title{
Community Ecology and Learning by Expanding. A Learning Community for Educational Transformation
}

\author{
María José Sosa Díaz ${ }^{1}$ María del Carmen Garrido Arroyo² \\ 1 University of Extremadura, Department of Education Sciences, Faculty of Teacher Training, Avenue of the University \\ ES-10003, Ca-ceres, Spain, mjosesosa@unex.es \\ 2 University of Extremadura, Department of Education Sciences, Faculty of Teacher Training, Avenue of the University \\ ES-10003, Ca-ceres, Spain, cargarri@unex.es
}

Anotacija. Learning by expanding is a model of learning that enables an analysis of how learning occurs in an educational community where relationships between its members and participation are essential for social transformation. With this concept as a starting point, a research methodology has been developed which aims to describe, record, and analyze how the process of learning by expanding can occur in different systems of activity; and/or, discover obstacles, difficulties, and challenges.

Keywords: learning by expanding, learning ecology, community ecology, case study, qualitative investigation, alternative education, learning community.

\section{Introduction: Expansive learning}

Education is complex and currently, the increase and expansion of different learning environments, as well as the presence of new forms of socialization is evident, making it necessary to identify, analyze and acknowledge learning processes as well as the mechanisms that facilitate them. This complexity of the educational phenomenon requires an "ecological way of thinking» that will enable "defense of epistemological diversity as a starting point and basis to approach the complex issues of education» (Fernández \& Martínez, 2018, p. 15). Therefore, the concept of learning ecologies enables one to 
identify contexts, agents and characteristics of new forms of learning, considering the acquisition of knowledge

from four dimensions or perspectives: a) personal learning ecologies, developed throughout life; b) resource ecologies, the individual uses of cultural and environmental tools; c) community ecologies, generated in experiences and relations in diverse cultural ecosystems; d) knowledge ecologies, where the knowledge of agents and communities is recognized (Fernández \& Martínez, 2018, p. 13-14).

Community ecologies, the third dimension or perspective of learning ecologies, are considered institutive participatory and social transformation spaces (Haythornthwaite, 2015; López et al., 2002; Martínez \& Fernández, 2018, p. 24). From this perspective, the community is where the model of learning by expanding is located, where the pedagogical, technological, and sociocultural dimensions are present and complement each other.

In 1987, Engeström systematized the concept of learning by expanding and it was subsequently developed with abundant research (Engeström, 1987; 1999; 2000; 2001; 2007; 2016, Engeström \& Sannino, 2010; 2016). This concept refers to

the process by which an individual, within the scope of practice, transforms or modifies the repertory of their culture to act differently to what would have been the case if their set of cultural provisions had not changed. This, in short, could be described as the transformation that takes place within a scope of activity, understood as the basic unit of human cultural action. (Sepúlveda, 2001, p. 2).

Engeström (1987; 2001) asks four questions to develop his model of learning by expanding, which should be answered by any theory of learning: (1) Who are the subjects of learning? How are they defined and located? (2) Why do they learn and what leads them to make an effort? (3) What do they learn and what are the contents and results of learning? (4) How do they learn? What are the key actions or processes of learning?

As a starting point, this author uses the concept of Zone of Proximal Development, introduced by Vygostsky (1978) and the Activity Theory by Leontèv (1981, p. 210-213), from which he creates his theoretical model of learning by expanding, considering that learning takes place through social collaboration by the construction of networks of activity systems, composed of individuals, cultural artefacts and society (Engeström, 1987, p. 78). Moreover, it is necessary to take into account the core principles that it establishes and which should be fulfilled by the Activity Theory (Engeström, 2000):

- A system of collective activity mediated by artefacts and which is object-oriented, is used as the main unit of analysis.

- An activity system is always a community of multiple points of view, traditions, and interests.

- An activity system takes shape and is transformed over long periods. Its problems and possibilities can only be understood by its history. 
- Contradictions are sources of change and development. Contradictions are structural tensions that often generate disturbances and conflicts but also result in innovative attempts to change an activity.

- Activity systems move through cycles that promote qualitative transformations. An expansive transformation is achieved when the object and the motive of the activity are reconceptualized.

According to this learning by expanding model, the key activity is the element or aspect whose ultimate purpose is to transform an aspect of reality, always based on the relationship between different individuals who have analyzed a problem and established a common need, which is the motive or object that links them (Engeström, 2007). In this context, the contradictions that arise within the group acquire high value and they are the elements that trigger a collective transformation and the thrust towards changing reality (Engeström \& Sannino, 2010). This makes them an element to be identified and analyzed.

In this respect, Engeström (1987) proposes the Activity Triangle, where he identifies the most important elements and the relationships between them. This is a clear diagram to analyze and understand what occurs in these learning contexts.

\section{Figure 1}

Activity Triangle (Engeström, 1987)

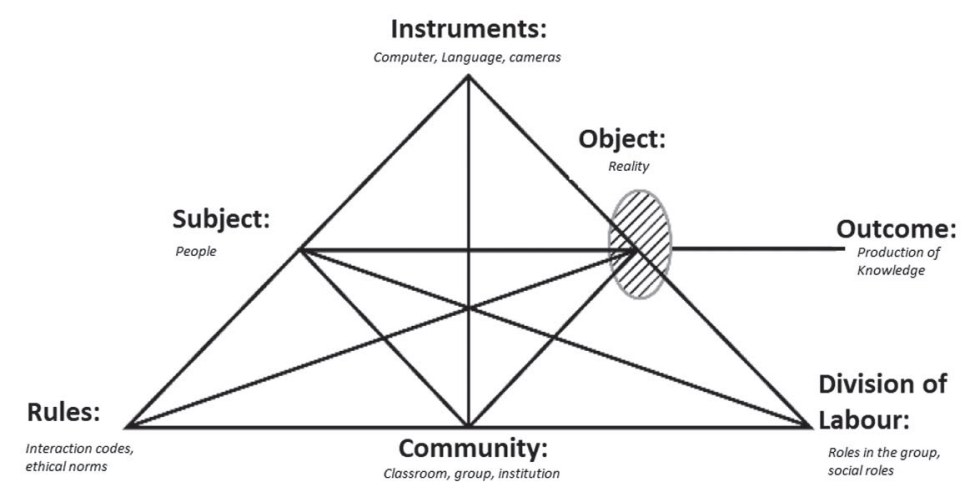

Learning by expanding has two elements that help in understanding it, which are, firstly, the forms of learning and secondly, the social nature of individuals.

Regarding forms of learning and following Bateson (1985), three levels of learning can be identified, thanks to which we will identify «how one learns». The classification, proposed according to processes carried out by the subject, differentiates between: (a) First order learning or learning I: which take place by conditioned reflexes, where the correct answers are given in a specific context; (b) Second order learning or learning II: learning that implies acquisition of behavior patterns and own behavior in a context; and (c) Third order learning or learning III: in which critical questioning takes place 
because the person or group consider the meaning of the context, question it and decide to propose new options.

Thus, learning by expanding would be third order learning, as it is the person or group who builds the problem, also responding and giving a solution to its contradictions. This capacity to solve and self-regulate «reminds us that systems transform themselves in response to changes that take place in their surroundings» (López, 2003, p. 146), being able to advance and propose alternatives to problems.

Regarding the social character of individuals, the second contextualizing element of learning by expanding, is valued by Wenger (2001) as an essential aspect of learning and equally relevant for the theoretical perspective that is the basis of Engeström's learning by expanding (2007), stating that learning is not an individual process, nor is it independent from everyday activities. Instead, contrarily, learning takes place through social collaboration and activity is an essential element to reach the ultimate goal, which is social transformation and where collective dialogue and the community have a relevant role, facilitating and enabling the creation of knowledge and the transformation of reality (Garrido, Sosa \& Arriazu, (2018, p. 230). These transformations imply changes in the culture of the individual and take place within what is called «activity» (Sepulveda, 2001). Learning takes place when an individual tries to resolve the contradictions generated within a non-stable context and in a framework of social collaboration indispensable to generate solutions shared in the community or organization they belong to (Garrido et al., 2018, p. 231).

Even so, we consider that to understand learning by expanding, we should bear in mind that learning will take place when the individual tries to resolve contradictions generated within a non-stable context and in a social collaboration framework that is indispensable to generate shared solutions in the community or organization they belong to (Engeström, 2001; 2007).

In this manner, culture also acquires relevance in the learning process, as it is thought that the individual will modify the cultural repertory, provoking a different form of action. Likewise, there will be transformations in the «activity», a basic unit of human cultural action, in which a process takes place by which the individual modifies the background of their culture to act differently to what would have been the case if the collection of their cultural provisions had not changed (Sepúlveda, 2001). So, one of the key aspects of the model is the consideration that learning occurs through social collaboration by building networks of «activity systems» composed of individuals, cultural artefacts, and society. According to López Yañez (2002) «learning appears as a property of the complex systems by which they face the complexity of their environment and their own structures; also like a process based on communication, which produces these structures by which the organization reaches a type of integrated operation, coherent with its own internal logic» (p. 93). 
Therefore, in learning by expanding, activity is a fundamental element, the ultimate goal of which is to transform one aspect of reality and which originates in the relationship between different individuals who have analyzed a problem and established a common need, this being the goal or motivation that unites them. Within this activity, a collection of interrelated actions takes place between them, configuring an «activity system», i.e., a collection of system networks. Each of the actions that occur within the activity usually has a cyclical development and includes transition mechanisms through contradictions that the community displays, which are the reason for the change (Engeström et al., 2013).

\section{Figure 2}

Learning Cycle (Engeström et al., 2013)

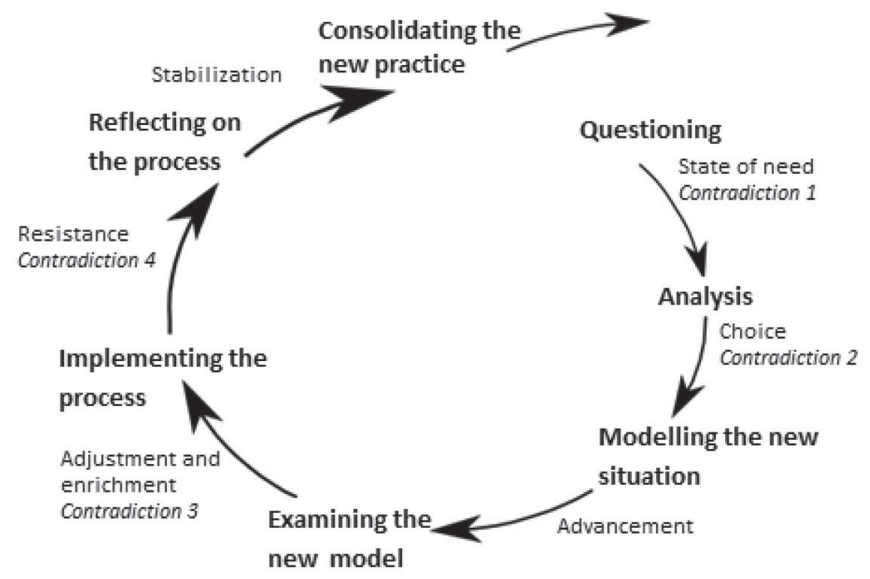

The analysis of each action implies identifying and analyzing reasons, conditions, results, regulation of the action, establishment of order and procedures for execution. Likewise, it is necessary to analyze the sequence, rules, and conditions established by the group to carry out any process.

Even so, this is a theoretical model of learning that is mainly characterized by having a transforming and horizontal learning dimension, as knowledge is created and reality transformed through collective dialogue (Engeström, 2007).

Collective dialogue is an element that must be present in educational communities, where relationships between members and participation are essential elements for social transformation. Many examples can be found of these communities, the study, and analysis of which will enable a more precise specification and more profound knowledge of the theoretical model of learning by expanding. 


\section{Methodology}

\section{Research Methodology}

Due to the characteristics of the research problem being dealt with, the objectives set out and various other reasons, the decision was made to carry out a qualitative cutting methodology. Firstly, qualitative research involves an interpretive and naturalistic approach to the world (Stake, 1998, p. 46), which allows us to study things in their natural context, trying to make sense, or interpret phenomena according to the meanings that people give them (Denzin \& Lincoln, 2005, p. 3). In addition, expansionary learning is a complex phenomenon and only qualitative methodologies allow understanding and interpretation from a comprehensive, holistic and in-depth analysis of this type of phenomenon (Strauss \& Corbin, 2002, p. 12). In this regard, the search for causal relationships is renounced and the establishment of global relations is chosen, always seeking to preserve the complexity of the phenomenon and direct applicability in the context.

\section{Research objectives and questions}

In any qualitative research, it is important to establish objectives and questions to direct the attention and process that will be carried out. As Stake (1998) proposes, the questions elaborated in this research have been organized in dimensions and topics extracted from a brief bibliographic review, which form a conceptual structure for the researcher.

- Identify and analyze key elements in the activity system developed in an educational community.

(a) Who are the learners and how are they defined and located?

(b) Why do they learn? What leads them to make an effort?

(c) What do they learn? What are the contents and results of learning?

- Analyze the characteristics of cyclical learning by expanding processes in an educational community.

(d) How do they learn? What are the key actions or learning processes?

\section{Case study}

In order to answer the questions raised above, a qualitative methodology based on Case Studies will be used. It is considered to be an excellent methodology when there are many dimensions of interest and it is impossible to separate the dimensions to be analyzed from their context (Yin, 2009), which is precisely what happens in this study, where dimensions are completely contextualized. In addition, although the objective of the Case Studies is particularization, it will also be a very valuable research method owing that it allows us to obtain important information that can be transferred to other contexts (Stake, 1998, p. 47). 
In this research, the collective or community of practice «Espacio Libre Candil», which has arisen with the objective of building the «alternative» school as an educational project, will be taken as a unit of analysis and has as its main characteristic, horizontal and collective learning. This case is defined and delimited as a community of practices in which a series of interactions are developed and both learning and knowledge are exchanged. In this sense, it fulfills the three main dimensions of a community of practice established by Wenger (2002): a) common task or objective; b) rules and commitments acquired by the group; and c) a shared repertoire or actions such as procedures, practical knowledge, routines, productions.

\section{Data collection techniques}

Due to the objectives set out in the case study, two different data collection techniques were used. Participating in each of them, were members of the collectives according to their involvement and role:

\section{Group Interviews}

On the one hand, group interviews were the resource for collecting information to analyze the key aspects of learning, since the perception of the members of the collective is especially important (OBJECTIVE 1). They were to be semi-structured interviews based on questions with open answers determined previously in a protocol or script of questions, with the intention of obtaining data relevant to the research. The question protocol can be found in Annex 1.

As can be seen in Table 1, the groups were formed according to the roles that individuals assumed within the collective such as teachers/companions, families and those with management/organization roles. Thus, three group interviews were conducted, each consisting of three people who assumed the same role.

\section{Non-participating observation in pedagogical assemblies}

On the other hand, non-participating observation was the information-gathering technique for analyzing learning cycles that occur within the collective (OBJECTIVE 2). The collective works by making decisions in a joint way and by means of assembly, so it was considered of vital importance to make non-participant observation of the learning process that took place in the development of the pedagogical assemblies that were carried out periodically. Audiovisual register was carried out of two assemblies that occurred naturally and without intervention by the researcher.

Each of the assemblies were made up of people who naturally participated in the activity that day, without prior notice of the investigator's observation, so as not to interrupt the number of participation that would usually take place in the assemblies. As can be seen in Table 1, the three companions/teachers attended the meeting along with about 10 fathers or mothers. 
Table 1

Data Collection Techniques and Number of Participants

\begin{tabular}{llllc}
\hline \multicolumn{1}{c}{ Objective } & $\begin{array}{c}\text { Data Collection } \\
\text { Technique }\end{array}$ & $\begin{array}{c}\text { Collection of } \\
\text { Data }\end{array}$ & Participant Role & $\begin{array}{c}\text { Num- } \\
\text { ber }\end{array}$ \\
\hline $\begin{array}{l}\text { Objective 1. } \\
\text { Key Learning } \\
\text { Elements }\end{array}$ & Group interview & Motor group 2 & $\begin{array}{l}\text { Management/ } \\
\text { Organisation }\end{array}$ & 3 \\
& Motor group 3 & $\begin{array}{l}\text { Companions/ } \\
\text { Teachers }\end{array}$ & 3 \\
& & & $\begin{array}{l}\text { Companions/ } \\
\text { Teachers }\end{array}$ & 3 \\
$\begin{array}{l}\text { Objective 2. } \\
\text { Cycle of Expansive } \\
\text { Learning }\end{array}$ & $\begin{array}{l}\text { Non-participato- } \\
\text { ry Observation }\end{array}$ & & Fathers/ Mothers & 3 \\
& & Assembly 2 & Teachers & 3 \\
& & & Fathers/ Mothers & 11 \\
Total participants & & & & 3 \\
\hline
\end{tabular}

\section{Access to the field study}

In order to update the collective on their selection for participation in the research, it was requested to participate in an assembly to explain the objectives and commitments to develop the research. The aim was to encourage subjects to participate actively in the research and to allow the researcher to enter the educational center without any inconvenience. During the assembly, the method of data protection for participants was also explained, as well as reporting on how and when the organization was selected and the process that the researcher had designed for the study development.

\section{Data analysis}

\section{Data Analysis Process}

Grounded Theory has been the key to interpreting the results (Glaser \& Strauss, 1967; Strauss \& Corbin, 2002). To this end, The Procedure of Constant Comparison of the Fundamental Theory has been adapted to the objectives of the present investigation.

Thus, four main stages can be identified in the data analysis:

Phase 1. Open coding. It is defined as «the analytical process by which concepts are identified and their properties and dimensions are discovered in the data» (Strauss \& Corbin, 2002, p. 110). Thus, the data was initially categorized and compared taking into 
account the system of categories and dimensions typical of expansionary learning (Engeström, 2001; Engeström et al., 2013). As such, a microanalysis of the information was developed, dividing into subunits of data and assigning them to those that were significant for the different categories and dimensions indicated in Tables 2 and 3.

Table 2

System of Categories and Dimensions of the Activity Triangle Linked to Objective 1

\begin{tabular}{ll}
\hline \multicolumn{1}{c}{ Categories } & \multicolumn{1}{c}{ Dimensions } \\
\hline Subject & $\begin{array}{l}\text { Which people } \\
\text { Profile of subjects }\end{array}$ \\
\hline \multirow{2}{*}{ Object } & $\begin{array}{l}\text { Philosophy or common reality } \\
\text { Common objectives } \\
\text { Motivations } \\
\text { Group identity }\end{array}$ \\
\hline Result of learning & $\begin{array}{l}\text { Contents learnt } \\
\text { Representation of the knowledge }\end{array}$ \\
\hline Rules & $\begin{array}{l}\text { Interaction codes } \\
\text { Ethical norms }\end{array}$ \\
\hline Community & $\begin{array}{l}\text { Group identity } \\
\text { Participation, involvement and commitment to the group }\end{array}$ \\
\hline Division of work & $\begin{array}{l}\text { Roles in the group } \\
\text { Internal structures and hierarchies }\end{array}$ \\
\hline Resources & $\begin{array}{l}\text { Digital devices } \\
\text { Communication tools }\end{array}$ \\
\hline
\end{tabular}

Table 3

System of Categories and Dimensions of Expansive Learning Actions Linked to Objective 2

\begin{tabular}{ll}
\hline \multicolumn{1}{c}{ Categories } & \multicolumn{1}{c}{ Dimensions } \\
\hline \multirow{3}{*}{ Questioning } & Challenging participants in the interrogation \\
& $\begin{array}{l}\text { On criticizing existing practices } \\
\text { Questioning the proposed development, analyzing }\end{array}$ \\
\hline & Need for articulation and ideas \\
& Historical analysis \\
Analyzing & Problems of articulation or challenges \\
& Identifying contradictions \\
& Alternative solutions \\
\hline & Initial idea of a model \\
& Exploiting the existing models or concepts \\
& Denomination and definition of the model \\
Modeling & Fixing the material or graphic model \\
& Variation and adaptation of the model \\
\hline
\end{tabular}




\begin{tabular}{|c|c|}
\hline Categories & Dimensions \\
\hline \multirow{3}{*}{ Examining the model } & Critical discussion of the model \\
\hline & New tools \\
\hline & Enriching the model \\
\hline \multirow{3}{*}{ Implementing } & Demonstration of application \\
\hline & Obstacles \\
\hline & Preparing implementation \\
\hline Reflecting on the process & $\begin{array}{l}\text { Consolidating and generalizing the new practice } \\
\text { Potential }\end{array}$ \\
\hline
\end{tabular}

Phase 2. Axial coding. This procedure is defined as an in-depth analysis of a category that aims to discover the interactions and relationships between it and other categories/ subcategories or properties (Strauss \& Corbin, 2002, p. 135). This analysis of data goes hand in hand with the physical grouping of the interpretations of each of the subunits of information that are part of the same category. As a final result, we have different matrices such as the learning matrix (Table 4) or the different learning cycle matrices produced (Table 5). The construction of matrices has become a very useful tool and a great help for the work of creating and validating conjectures (Conde, 2009, p. 200). This procedure explicitly revealed the most --common data and parties, allowing us to consider, reflect and determine what the main ideas were and answer questions, (such as: why? where? when? with what?) that are typical of axial coding (Strauss \& Corbin, 2002, p. 138). In the end, a synthesis and selection of the most important information is carried out, accompanied by the creation of memoranda in which first impressions of the collected data are scored.

Phase 3. Selective or theoretical coding. Theoretical coding «re-weaving fractured history» (Glaser, 1967, p. 72). Now is the time to recompose the data and give coherence to the emerging analysis. Thus, using the most relevant matrices, memoranda and information, theoretical writing was carried out, the findings were scored and those results integrated into the initial Emgeström Expansive Learning Theory, modifying/building and expanding the theory.

Stage 4. Theoretical saturation. The data collection is concluded, as no new ideas and relationships emerge that expand the research and the results of this work are described (Strauss \& Corbin, 2002, p. 149).

\section{Software used in research}

For data analysis, in order to increase quality and rigor within the research, we have specifically used the following software for different tasks:

1. Digital Voice Editor software has been used to transcribe interviews and assemblies in order to listen to separate audios. 
2. Open Office Write has been used to produce memos and thoughtful comments on some aspects of the data and write interim and final reports.

3. THE NVIVO qualitative analysis program has been used to code, store, search and retrieve data in the analysis, as well as to analyze the content, count frequencies, sequence, or locations of words and phrases. THE NVIVO software is a program that aims at theoretical construction through the analysis of the texts, although in the present research study, only basic functions, like tracing, coding and accounting have been used.

\section{Results}

\section{Activity Triangle}

«Espacio Libre Candil» is a group formed by attendants, families, and their children from 0 to 6 years of age. Each member has a role in the group, and all participate together in its organization and development. The group was formed at the initiative of several families with common interests. The professions of the families are usually related to the social sphere, and they are critical with the traditional school model.

«Well, that's it, the origin of the group is a few families and people who got together with concerns about having a different kind of education, then, we thought that education is key to being better people and generating new societies. » (Philosophy, Motor Group 2).

The philosophy of the group is built from different premises to that of the educational model to be developed: a) Teaching that is respectful to the needs of children. b) Free pedagogy based on games. c) Learning takes place during one's whole life. d) The importance of developing critical thought and decision-making. e) Public education for everybody.

Observing that the traditional educational model does not comply with most of these premises, they consider creating an alternative space to educate their children according to their ideas and to try to contribute, in some way, to changing the educational paradigm with their center.

«Then, from the group, we want to change education, culture. An alternative politics, economy and technology [...] We are clearly aware of what we can do with this school, that's it, this group does what it can.» (Common goals, Motor Group 2).

However, the group needs to push the envelope and one of their goals is to expand the educational model to other centers and levels, to which end, they carry out negotiations with other educational institutions to evaluate the possibilities.

«Then the line of Primary school is also channelled to what is really a center for educational innovation that gradually influences other centers and other professionals.» (Common objectives, Motor Group 1). 
Over the years, the group has formed a strong group identity: «we share values, attitudes, we believe and understand that the education traditionally imparted in schools has preferentially developed cognitive aspects and has somewhat sidelined the physical, emotional, social, moral and spiritual aspects» (Group Identity, Motor Group 2). In this respect, the pedagogical project of the group is made by the whole group, a result of learning, experience, and the influence of the hired accompanying people, so that this group identity is modified and transformed in time according to the participants.

«Because we understand that pedagogy is not a monopoly of teachers, but rather something from the group.» (Motor Group 3).

Nevertheless, "we are a group, and there are forces that move more to one side and others that move to another» (Group Identity, Motor Group 1) and it is sometimes difficult to build a model that is common to all. This is very habitual in the development of the school course. However the group knows clearly that what is important are the people, reaching agreements, and considering that decisions are made by all the members. Indeed, despite the difficulties, participating in the group is also considered positively by its members.

«To be in the group is very hard work and very gratifying, for me, it is like a roller coaster when you go up, look how well things are going and suddenly, well, things go wrong.» (History, Motor Group 2).

The division of work and organizational structures have both changed over time, according to the circumstances of each of the school years and the interests of the group members. This proves that the organizational structure adapts better and is more efficient in the group. Currently, the work commission system is working. Nevertheless, due to a lack of coordination, time and connection between the different commissions, there is no self-evaluation of the process which does not produce effective results.

«Well, having organized the fact that there is no good regulation, there is not a good self-evaluation of the commissions, i.e., the commissions have been asked for information about how they are getting on with the work, work minimums and this is not being done. Then, we still need a lot of evaluation.» (Interaction codes, Motor Group 1).

Decisions have always been made horizontally, through assemblies with the participation of families as well as attendants. For the group, every opinion is very important along with the ideas and contributions of all members. In this respect, the assembly is a very important tool to achieve this goal, as this space gives a voice and vote to everyone who wants to participate. There is an unwritten principle on the need of everyone to be in agreement with the decisions made in the assemblies. Thus, the mechanisms for everyone to feel identified with the decisions made is by the establishment of agreements, and not by majority vote.

«In the end, we are not aiming for a majority, but rather trying to reach an agreement altogether. Therefore, if anyone refuses outright, we try to reach an agreement, and 
that takes time, and sometimes things take a long time.» (Communication tool, Motor Group 1).

Nevertheless, the horizontal organization of the group sometimes hinders decision-making, which becomes slow, mainly because the families have other responsibilities and do not have enough time for $100 \%$ involvement in the group.

"We still lack time, that is to say, you don't know if we can overcome the fact that an adult who has children and a job can participate sufficiently, can spend sufficient time in the organization of the center.» (Participation, involvement, and commitment, Motor Group 1).

Moreover, the group has difficulties working with assemblies, as this is not habitual in their personal or professional life. For this reason, all the participants in the group still have to learn and develop mechanisms to debate and reach agreements.

«It is difficult for the families, the people who form the group, because we don't have that experience, then what happens? There are things that take a long time.» (Communication tools, Motor Group 2).

Nevertheless, despite the difficulties, it can be seen that the group is an educational community that learns by sharing ideas, discussing opinions, building a project together, and working towards a common goal.

«Enrichment provided by the group, we all contribute ideas and participate, it's very enriching to belong and grow and even more in this project that is so beautiful and important for us, as it makes it a very big advantage.» (Contents learnt, Motor Group 2).

One of the results of learning can be seen in the creation and development of the "little school" project, this project has been the main goal of the group and its construction has not been easy, and it a process of continuous learning. The educational project has been evolving, decisions have been made, and agreements reached on different aspects such as the structure of the educational spaces or the presence of adults in the little school, among others.

«Regarding how the families are in the space. Well, the first year, as you can imagine, there were a lot of arguments about when the families are in the space and when the families are not in the space and last year, there was a need for the older children to move up». (Contents learnt, Motor Group 1).

The motor of this learning is often the contradictions identified, which encourage confrontation of philosophy or learnt attitudes, with the aims of achieving in their «little school» project. In general, three contradictions have been found:

Contradiction 1: They want a horizontal space, where everyone participates in the decisions. However, not all families participate or can participate equally. Therefore, the structure of the group has been changed, as the group and its circumstances evolve.

«We still lack participation and time, in other words, you don't know if we can overcome the fact that an adult with children and a job, can participate sufficiently, spend time in the organization of the center.» (Participation, involvement, and commitment, Motor Group 2). 
Contradiction 2: It declares to have a group identity based on a different philosophy of education from the traditional. However, they state they are not sure about the educational model.

«And we never had a clear method, nor do we have it, that is to say, the attendant of the moment and then last year those that were there and this year those who are here.» (Which people learn, Motor Group 2)

Contradiction 3: Search for an educational change from a private initiative.

«But what we were sure of was that we needed an alternative, something different because we were not convinced with what existed [...] then, through education, we think we can change many things. [...] We enter the vacuum of up to 6 years old, but they cannot give us any subsidy because really, that is to say, in any case, it would be as an association, but as an association, it does not work.» (Economic management, Motor Group 2)

The following learning matrix can be used to systematize the discourse on learning by expanding produced in the case study of the «Espacio Libre Candil» group, responding to the questions who, why, what and how one learns (Table 4).

Table 4

Learning Matrix

\begin{tabular}{|c|c|c|c|c|c|}
\hline & $\begin{array}{l}\text { The activity } \\
\text { system as a } \\
\text { unit of analysis }\end{array}$ & $\begin{array}{c}\text { Multiple } \\
\text { points of view }\end{array}$ & History & $\begin{array}{l}\text { Contra- } \\
\text { dictions }\end{array}$ & $\begin{array}{c}\text { Expansive trans- } \\
\text { formations in } \\
\text { cycles }\end{array}$ \\
\hline $\begin{array}{l}\text { Who } \\
\text { learns? }\end{array}$ & $\begin{array}{l}\text { Members of } \\
\text { the Colectivo } \\
\text { Candil }\end{array}$ & $\begin{array}{l}\text { Heterogene- } \\
\text { ous members, } \\
\text { with different } \\
\text { views on } \\
\text { education }\end{array}$ & & & \\
\hline $\begin{array}{l}\text { Why } \\
\text { learn? }\end{array}$ & & & $\begin{array}{l}\text { The result of } \\
\text { a parenting } \\
\text { group } \\
\text { United due } \\
\text { to their link } \\
\text { to respectful } \\
\text { parenting and } \\
\text { attachment }\end{array}$ & $\begin{array}{l}\text { Search for an } \\
\text { educational } \\
\text { change from } \\
\text { private initi- } \\
\text { ative }\end{array}$ & $\begin{array}{l}\text { The fight for an ed- } \\
\text { ucational change } \\
\text { that promotes } \\
\text { respectful educa- } \\
\text { tion adapted to the } \\
\text { pace of learning } \\
\text { and interests }\end{array}$ \\
\hline $\begin{array}{l}\text { What is } \\
\text { learnt? }\end{array}$ & $\begin{array}{l}\text { Educational } \\
\text { project Little } \\
\text { school }\end{array}$ & $\begin{array}{l}\text { Contents and } \\
\text { knowledge of } \\
\text { different peda- } \\
\text { gogical models }\end{array}$ & & $\begin{array}{l}\text { They are not } \\
\text { clear about } \\
\text { the educa- } \\
\text { tional model } \\
\text { to be deve- } \\
\text { loped }\end{array}$ & $\begin{array}{l}\text { Aspects of the edu- } \\
\text { cational model to } \\
\text { follow within the } \\
\text { Little school pro- } \\
\text { ject, such as spaces } \\
\text { or the presence of } \\
\text { adults }\end{array}$ \\
\hline
\end{tabular}




\begin{tabular}{|c|c|c|c|c|c|}
\hline & $\begin{array}{l}\text { The activity } \\
\text { system as a } \\
\text { unit of analysis }\end{array}$ & $\begin{array}{c}\text { Multiple } \\
\text { points of view }\end{array}$ & History & $\begin{array}{l}\text { Contra- } \\
\text { dictions }\end{array}$ & $\begin{array}{c}\text { Expansive trans- } \\
\text { formations in } \\
\text { cycles }\end{array}$ \\
\hline $\begin{array}{l}\text { How they } \\
\text { learn }\end{array}$ & $\begin{array}{l}\text { Holding assem- } \\
\text { blies during the } \\
\text { course }\end{array}$ & $\begin{array}{l}\text { All have the } \\
\text { same possibil- } \\
\text { ities of being } \\
\text { listened to and } \\
\text { making deci- } \\
\text { sions }\end{array}$ & & $\begin{array}{l}\text { The involve- } \\
\text { ment and } \\
\text { participation } \\
\text { of families is } \\
\text { not always } \\
\text { as much as } \\
\text { desired }\end{array}$ & $\begin{array}{l}\text { Agreements are } \\
\text { established to im- } \\
\text { plement chang- } \\
\text { es or solutions to } \\
\text { possible situations } \\
\text { that arise }\end{array}$ \\
\hline
\end{tabular}

All of this proves that the group provides continuous learning by expanding, which makes their organization change and evolve over time. «Espacio Libre Candil» is a group of people united by their links to respectful parenting and the fight for a change in education that promotes a new model. Therefore, their objective is to build a small school that can offer this type of education to their children. For this purpose, they form a group organized horizontally through commissions in which the functions and tasks of the group are shared out, and assemblies are used to make decisions and the creation of the educational model they want for the little school project. In these assemblies, all the ideas, opinions, and suggestions of each of the members are taken into account.

\section{Figure 3}

Activity Triangle (Adapted From Engeström, 1987)

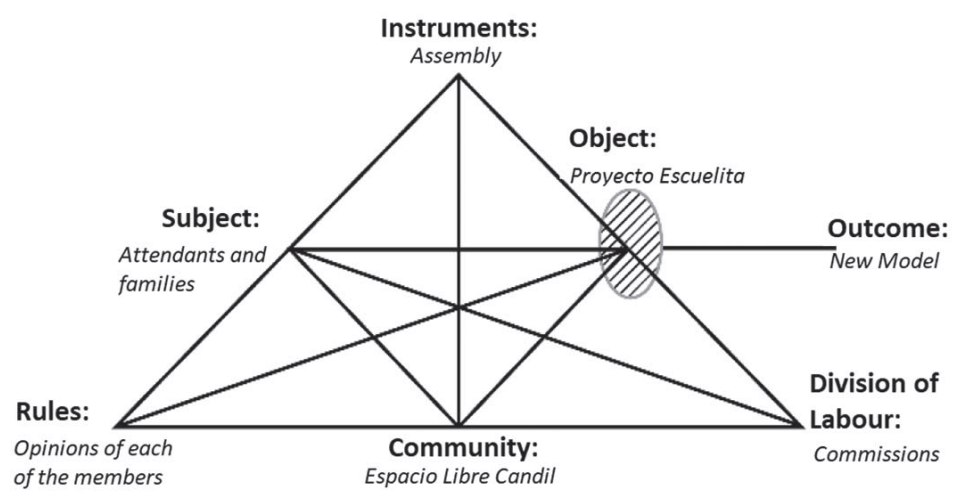

\section{Identification of the learning by expanding cycle}

Here we will present an integral analysis of the learning of the group carried out through the assemblies held once a month to monitor the development of the educational practice and the solution to problems that arise during the school term. For this purpose, transcriptions of two assemblies were analyzed, and the cycles of learning and their phases were identified. 
As shown in Table 5, throughout the assemblies analyzed, 22 different learning cycles were found. As seen in the table, both assembly 1 and assembly 2 recorded 15 learning cycles.

Table 5

Learning Cycles Produced

\begin{tabular}{|c|c|c|c|c|c|c|}
\hline Learning cycles & $\begin{array}{c}\text { Assembly } \\
1 \text { Refe- } \\
\text { rence }\end{array}$ & $\begin{array}{c}\text { Assembly } \\
1 \text { words }\end{array}$ & $\begin{array}{c}\text { Assembly } \\
2 \text { Refe- } \\
\text { rence }\end{array}$ & $\begin{array}{c}\text { Assembly } \\
2 \text { Words }\end{array}$ & $\begin{array}{l}\text { Total No. } \\
\text { of referen- } \\
\text { ces }\end{array}$ & $\begin{array}{l}\text { Total } \\
\text { No. of } \\
\text { words }\end{array}$ \\
\hline Rest day & 1 & 39 & 0 & 0 & 1 & 39 \\
\hline Day off & 2 & 182 & 0 & 0 & 2 & 182 \\
\hline Food for children & 1 & 185 & 0 & 0 & 1 & 185 \\
\hline Pedagogical commission & 10 & 1368 & 2 & 365 & 12 & 1733 \\
\hline Didactic material & 2 & 571 & 0 & 0 & 2 & 571 \\
\hline New space & 3 & 673 & 3 & 52 & 6 & 725 \\
\hline Accompaniment model & 3 & 941 & 5 & 681 & 8 & 1622 \\
\hline Norms and routines & 3 & 1403 & 1 & 3 & 4 & 1406 \\
\hline $\begin{array}{l}\text { Communication } \\
\text { families-attendants }\end{array}$ & 1 & 1607 & 1 & 18 & 2 & 1643 \\
\hline Educational workshops & 3 & 2895 & 0 & 0 & 3 & 2895 \\
\hline Evaluation and observation & 1 & 217 & 1 & 286 & 2 & 503 \\
\hline $\begin{array}{l}\text { Beginning and end of } \\
\text { course }\end{array}$ & 3 & 3464 & 1 & 230 & 4 & 3694 \\
\hline New Families & 1 & 646 & 1 & 1017 & 2 & 1663 \\
\hline Tutorials for families & 1 & 150 & 0 & 0 & 1 & 150 \\
\hline $\begin{array}{l}\text { Secretary/chairperson } \\
\text { Assembly }\end{array}$ & 1 & 70 & 1 & 350 & 2 & 420 \\
\hline Attendants team & 0 & 0 & 13 & 1545 & 13 & 1545 \\
\hline Group & 0 & 0 & 7 & 634 & 7 & 634 \\
\hline Programing & 0 & 0 & 11 & 1235 & 11 & 1235 \\
\hline Excursions & 0 & 0 & 1 & 893 & 1 & 893 \\
\hline Farewell party & 0 & 0 & 1 & 703 & 1 & 703 \\
\hline Maternity leave & 0 & 0 & 1 & 389 & 1 & 389 \\
\hline Holidays & 0 & 0 & 1 & 558 & 1 & 558 \\
\hline
\end{tabular}

Among the most controversial learning cycles are the «educational workshops», «beginning and end of course» and «communication between families-attendants».

The learning cycles are not characteristic of a single assembly, but rather some of them are taken up in later assemblies, as they are important topics or topics that have not been closed, such as, for example, «accompaniment model», «the pedagogical commission», «beginning and end of course» or «new families» among others. 
Moreover, some of the learning cycles are repeatedly discussed during an assembly, reflected in the number of references obtained in each of the learning cycles, such as, for example, «pedagogical commission» or «accompaniment model» with a total of 10 and 8 references respectively, which shows the importance of this learning cycle for the group and the possibility that the learning cycles do not need to occur continuously but can occur sporadically during an assembly session, interspersed between other learning cycles.

It is also necessary to highlight that two of the learning cycles proposed in the development of the assembly display mini-cycles. This is the case of «Pedagogical commission» and «Educational workshops» learning.

As shown in table 6, there were assemblies in all the learning by expanding actions. The most common learning by expanding actions were the action of «situation analysis» and «new situation modelling» with 214 and 165 references, respectively. Followed by «questioning of the practice» carried with 61 references and «examining the new mode» with 51 references. The least frequent actions in the development of the assemblies were «implementing» and «reflecting on the process», with 33 and 24 references.

Therefore, it can be said that participants in the assemblies typically focus more on analyzing the situation and modelling a new solution than examining the implementation model and reflecting on the consolidation of the new practice. The relatively low frequency of the implementation and reflexing actions on the process of the new practice may be due, to a large extent, to the fact that the monitoring of subsequent assemblies has not been included in this analysis.

Returning to the question of frequencies of the different learning actions, it can be seen that in each learning by expanding action, there are also other learning subactions. Among the most common are the «identification of needs» and «identification of problems or challenges» with 54 and 56 references respectively. Although the one that the group dedicates more time to is historical analysis, with 2357 words. Nevertheless, the one with fewer references and less time dedicated to it is the search for «new tools» offered by the new model being discussed.

\section{Table 6}

Learning Actions and Sub-Actions

\begin{tabular}{clcc}
\hline & \multicolumn{1}{c}{ Learning by expanding action } & Reference Nos. & No. of words \\
\hline Q. & \multicolumn{1}{c}{ Questioning } & $\mathbf{6 1}$ & $\mathbf{2 2 5 8}$ \\
\hline Q1. & Challenging the participants in the interrogation & 28 & 478 \\
Q2. & Criticizing existing practices & 24 & 1673 \\
Q3. & Questioning the proposed development analyzed & 9 & 107 \\
A. & Analysis of the situation & 214 & 8206 \\
A1. & Identification of needs and ideas & 54 & 2054 \\
A2. & Historical analysis & 45 & 2357 \\
A3. & Identification of problems or challenges & 56 & 1983
\end{tabular}


A5. Alternative solutions

M. Modelling the new situation

M1. Initial idea of a model 5729

M2. Exploring existing models or concepts

M3. Denomination and definition of the model

M4. Fixing the model

M5. Variation and adaptation

E. Examining the new model

E1. Critical discussion of the model

E2. Enriching the model

E3. New tools

I. Implementing the process

I1. Demonstrating the application

I2. Preparing the implementation

I3. Obstacles

R. Reflecting on the process

R1. Consolidating and generalizing the new practice

R2. Potential of the new practice

Figure 4 shows how the most common learning cycles in assembly 1 are more intense than in the cycles of assembly 2. This shows that they are two different types of assemblies, with different objectives. Remember that assembly 1 works on issues of coordination and conflictive issues on which agreements must be reached. Therefore, there is a prevalence of «situation analysis» learning actions with the «identification of needs, problems and contradictions» and «modelling the new situation» debating alternatives to solve. However, assembly 2 is a school course closure assembly, working mainly on actions of «questioning» especially «constructive criticism of current practice» (both positive and negative) and «situation analysis» where «needs are identified» for the next course and «they analyze the historical development». 


\section{Figure 4}

Recurrence of the Learning Actions in the Cycles

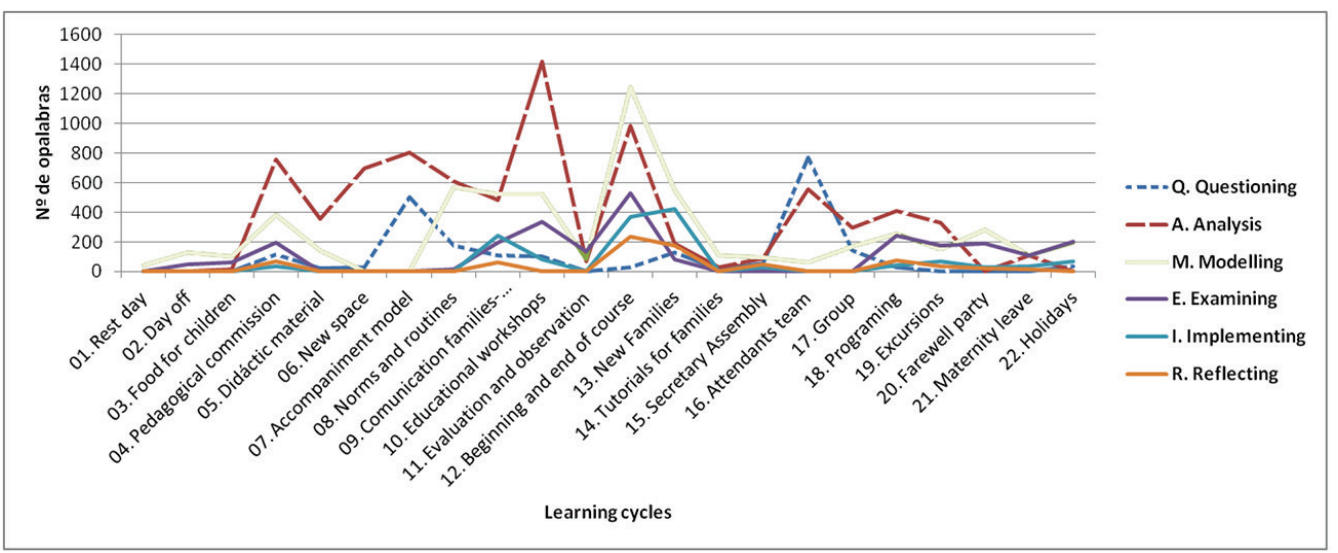

As can be seen in figure 5, in each of the learning actions, a wide variety of subtypes was found.

Nevertheless, not all the learning cycles develop all the subtypes of learning actions; neither do they necessarily go through all the learning actions. The average of learning sub-actions developed is 9.7. As can be seen in figure 4, some of the learning cycles only carry out a learning sub-action, such as «rest of companion day». However, this fact is not habitual, and typically, the minor amount of learning sub-actions more prevalent in each cycle is 4 or 5 sub-actions.

None of the learning cycles develop the 21 sub-actions. The one that generated more learning sub-actions was the "Pedagogical commission» learning cycle, with 19 subactions although this amount is not habitual, as the higher number of more frequent sub-actions in each cycle is 17 sub-actions.

Among the most frequent sub-actions are those belonging to the «analysis of the situation» action firstly and secondly those of «situation modelling».

Within the learning action of analysis, we can highlight the sub-action that more time has been dedicated to is that of «historical analysis», with 2357 words, although the sub-action that appears most frequently in the learning cycles is that of «needs analysis», and that with least presence is «analysis of contradictions»

In the case of the situation modelling learning action, the one that more time is dedicated to and which appears more frequently in the learning cycles is «initial idea of a model» with 1411 words and presence in 17 cycles.

Then, we can highlight the «critical discussion of the model» sub-action, with presence in 13 learning cycles and temporal dedication of 1843 words, followed by «criticism of the existing practice» with presence in 7 learning cycles and 1673 words, mainly due to the characteristics of the objective of assembly 2 , which was to evaluate the last school year. 


\section{Figure 5}

Recurrence of Learning Sub-Actions in the Cycles

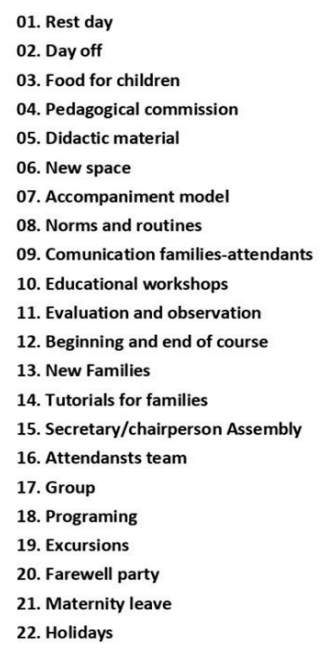

01. Rest day

03. Food for children

04. Pedagogical commission

13. New Families

14. Tutorials for families

15. Secretary/chairperson Assembly

16. Attendansts team

20. Farewell party

22. Holidays

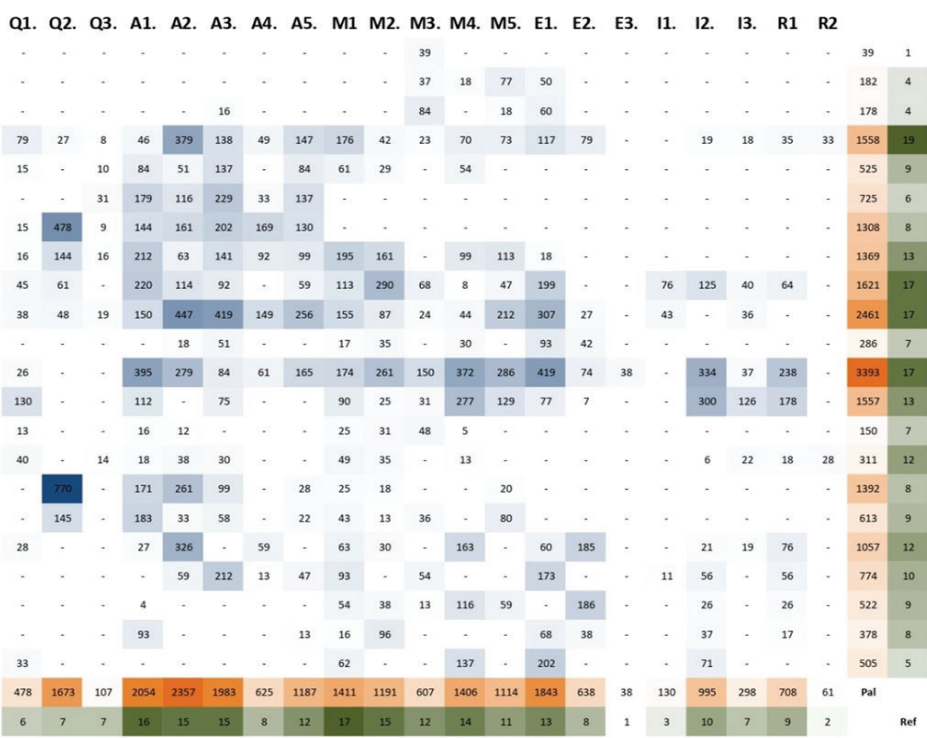

Considering the number of learning cycles that have been found within the assembly, we will now analyze two cycles of the most controversial, intending to identify and clarify the pattern followed by the different learning actions and sub-actions.

The «beginning and end of course» learning cycle is developed with a total of 81 learning sub-actions. And in the «educational workshops» learning cycle, there are a total of 54 learning sub-actions. As can be seen in figures 6 and 7, the learning cycles are slightly different, and the actions take place in different and diverse orders. Nevertheless, in each of the learning cycles, one can observe the succession of sub-cycles that are reflected in the line of the graph as peaks and troughs. The peak is the beginning of the cycle and the trough, the end of the cycle.

Within these learning sub-cycles, «analysis» and «modelling» actions take place alternately in most of the process. However, it must be highlighted that under no circumstances do all the learning sub-actions take place in action, and the process does not always end or begin at the same starting point. So, there are sub-cycles that only develop analysis and modelling sub-actions, while others end in the action of examining the model or developing the whole process.

It is necessary to comment that two aspects have been found that take place in the graphs in a different manner.

In the «beginning and end of course» cycle, it can be seen that once an agreement has been reached on the model to be implemented, this time, in a repeated and alternate manner, the «implementing» and «reflecting» actions take place until the mode considered adequate is reached. 


\section{Figure 6}

Description of the Learning Sub-Actions in the "Beginning and End of Course" Cycle

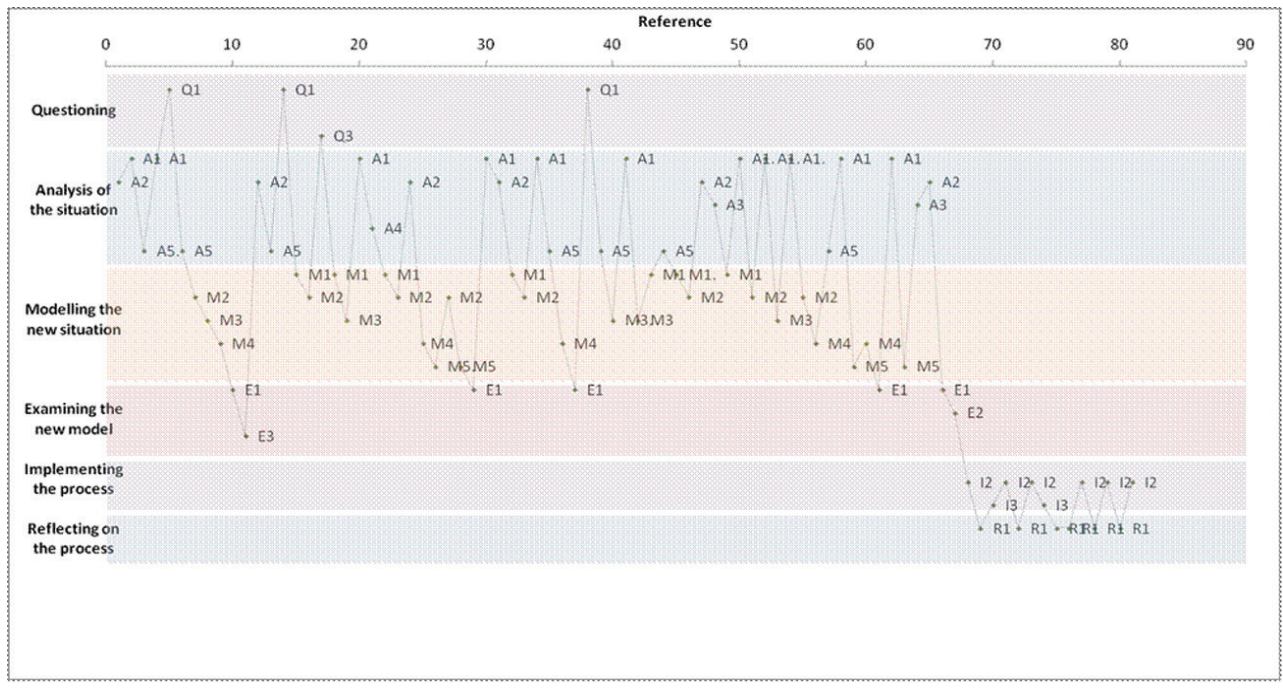

However, in the «educational workshops» cycle, despite considering the model to be implemented and establishing the basis for implementing it, the group again takes up the discussion to continue analyzing other options.

\section{Figure 7}

Description of Learning Sub-Actions in the "Educational Workshops" Cycle

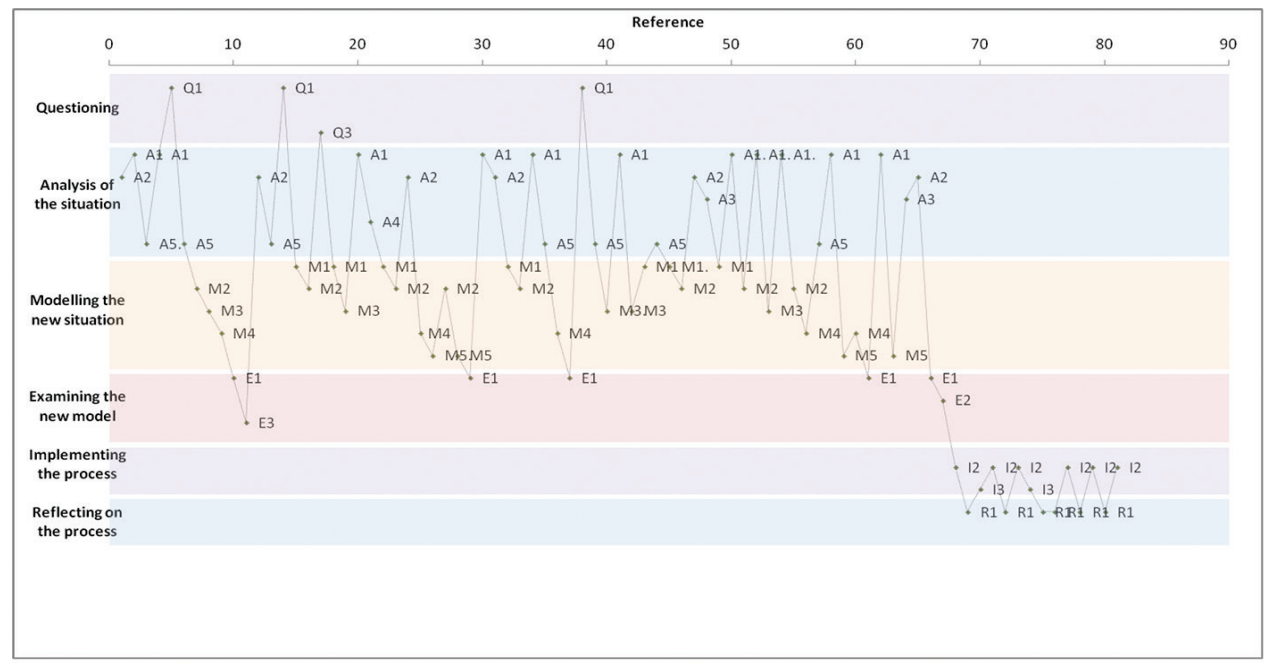

Although the learning cycles are, to a large extent, incomplete and do not develop all the learning actions, it can be seen that a cycle is made, in general terms, repeatedly. 
Therefore, the results obtained reveal firstly that not all sub-actions have the same importance, as there are actions that take place more than others, as is the case of «identification of needs», «identification of problems» «historical analysis» and «initial idea of a model» sub-actions.

Therefore, it can be said that the group focuses more on the aspects of the analysis of the situation and search for alternatives, than in exploring or establishing the strategies to implement a new model, which can lead to a failure of the model.

Secondly, our analysis of the cyclical nature of learning by expanding revealed an iterative loop in each of the learning cycles analyzed thoroughly. Nevertheless, the cycles are generally not complete and are focused mainly on the actions of analysis and modelling of the situation. These findings enrich and enlarge the understanding of the learning by expanding activity. Below, is a slightly modified version of the explanatory graph proposed by Engeström to explain the cyclical nature of learning by expanding, highlighting the importance of the partial loop occurring between the «analysis» and «modelling» actions.

Figure 8

Learning Cycle (Engeström, 2012)

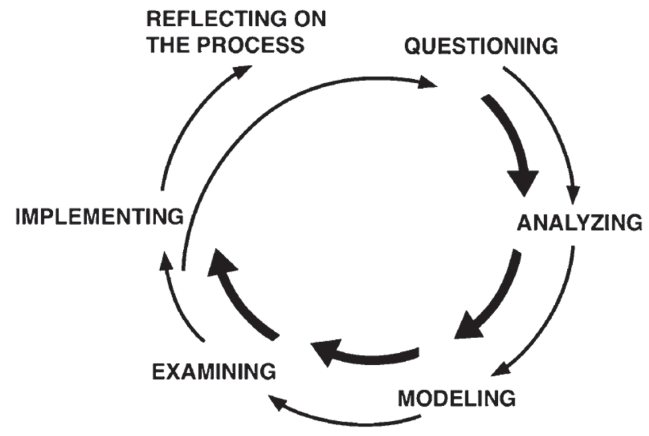

Figure 9

Learning Cycle (Developed by the Author)

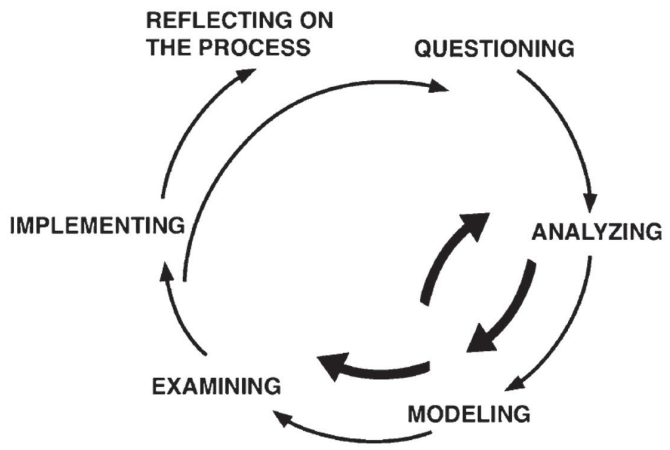


One of the most evident conclusions provided by this analysis is that learning is a cyclical process through which one progressively acquires higher levels of competence (Engeström, 2001). This analysis has enabled the identification of different types and subtypes of learning by expanding actions, although not all of them had the same importance (Engeström et al., 2013). Some actions are reproduced more than others, as is the case of the «identification of needs», «identification of problems», "historical analysis» and «initial idea of a model» sub-actions, leading to the conclusion that the group focuses more on the analysis of the situation and search for alternatives aspects, rather than exploring or establishing the strategies to implement a new model. This circumstance could suggest the possibility that the improvement model implemented will not be successful (Garrido et al., 2018)

Moreover, the analysis of the cyclical nature of learning by expanding revealed an iterative loop in one of the learning cycles, so it could be said that the cycles are not totally «linear», but that they can repeatedly focus on specific actions and sub-actions of learning or/and not develop the cycles completely.

\section{Discussion and Conclusions}

As can be seen throughout the study, the action of education is complex, and it is important to move towards a more ecological perspective of learning, focusing mainly on group and community dimensions (Fernández \& Martínez, 2018). An example of community ecology is the «Espacio Libre Candil» group, which according to its characteristics can be considered an a «institutive participative space and for social transformation» (Martínez \& Fernández, 2018, p. 24) due to the critical thought of the group that questions the context and decides to propose new options (Bateson, 1985).

From these concepts and considering the ecological characteristic of learning, a research methodology has been developed that aims to analyze the learning by expanding process as a learning model in human collective activities and describe what happens in the different activity systems and warn of obstacles and challenges in learning between agents in the different groups or communities (Engeström, 2013).

The analysis work has shown that the collective develops an Expansive Learning since it complies with the determining principles of the Theory of Activity (Engeström, 2000). It is mediated by artefacts, has multiple points of view, traditions and interests; it is transformed over long periods of time and there are continual contradictions and learning cycles. The analytical work has proven that the group being studied presents progressive learning by expanding, making the organization modify and evolving its own meaning over time (López, 2003, p. 146).

Analysis of the learning matrix has clarified who, what, why and how a group learns and has created the triangle of the activity (Engeström, 1987; 2001), as well as the 
contradictions that trigger learning and the different phases of learning by expanding in the development of an organizational assembly of this groups. Thus, «Espacio Libre Candil» is a collective formed by companions and families united by their connection, concerned with respectful upbringing and a struggle toward educational change that promotes respectful education, adjusted to the rhythms and interest in learning. For this reason, its objective is to build a small school that can offer this kind of education to its sons and daughters and have a social impact for educational change. Agreements are reached by collective, horizontal organisation and assemblies are used for decision-making in a democratic way, since the group are faced with various contradictions and tensions for which they must generate solutions (Garrido et al., 2018, p. 231). In these assemblies, all the ideas, opinions and suggestions of individual members are taken into account and learning cycles are generated through the construction of dialogs produced.

One of the most interesting results provided by this analysis is that learning is a cyclical process through which one progressively acquires higher levels of competence (Engeström, 2001). This analysis has enabled the identification of different types and subtypes of learning by expanding actions, although not all of them had the same importance (Engeström et al., 2013). Some actions are reproduced more than others, as is the case of the «identification of needs», «identification of problems», «historical analysis» and «initial idea of a model» sub-actions, leading to the conclusion that the group focuses more on the analysis of the situation and search for alternatives aspects, rather than exploring or establishing the strategies to implement a new model. This circumstance could suggest the possibility that the improvement model implemented will not be successful (Garrido et al., 2018)

Moreover, the analysis of the cyclical nature of learning by expanding revealed an iterative loop in one of the learning cycles, so it could be said that the cycles are not totally «linear», but that they can repeatedly focus on specific actions and sub-actions of learning or/and not develop the cycles completely.

According to the cyclicity analysis of expansive learning, an iterative loop was revealed in one of the learning cycles. It can therefore be said that the cycles are not completely «linear», but they can focus repeatedly on specific learning actions and sub-actions and/ or not develop cycles completely.

Finally, we consider that the study provides several conclusions of interest on the subject addressed.

We usually tend to represent learning as an individual and typically a one-way process. However, as has been demonstrated throughout the text, there are other forms of learning, generated from experiences and relationships experienced in diverse cultural ecosystems and which we can call community ecology.

The findings of this research reveal that the development of learning can occur in a group and attests to the creative capacity of communities of practice when one is given the opportunity to participate in the organization and management activity of institutions. 
This is mainly reflected in two learning outcomes in the present research. On the one hand, we see it in the creation and development of the school project and on the other, we see it coming from the social impact that promotes a change of the educational model in society.

The proposal for analysis from The Expansive Learning Theory has allowed us to identify and understand the horizontal learning process that occurs in a community of practices.

Firstly, the analysis of the learning matrix has made it easier to clarify who, what, why, and how the collective learns. In this sense, contradictions have been identified as an essential and detonating element of learning found in all communities of practice.

At the same time, the analysis of cyclicity of learning, reveals that collective dialog, through assemblies, has a relevant role to play in facilitating and enabling the creation of knowledge and the transformation of reality. In addition, it is observed that there is an iterative loop in each of the learning cycles, which enriches and expands the understanding of expansionary learning activity.

\section{Acknowledgments}

This work was supported by grants for the execution of investigative activities, technological development, the dissemination and transference of knowledge by the investigation groups working at the University of Extremadura. Ministry of Economy, Science and Digital Agenda. Junta de Extremadura (Spain) Ref. GR18071. National R\&D\&I Plan. Ministry of Science, Innovation and Universities (Spain) Ref. RTI2018-097144-B-I00.

\section{References}

Bateson, G. (1985). Steps towards an ecology of the mind. New York: Lohle-Lumen.

Conde, F. (2009). Sociological analysis of the discourse system (3th ed.). Madrid: Sociological Research Center.

Denzin, N. K., \& Lincoln, Y. S. (2005). The sage handbook of qualitative research. London: SAGE Publications.

Engeström, Y. (1987). Learning by expanding an activity-theoretical approach to developmental research. Helsinki: Orienta-Konsultit.

Engeström, Y. (1999). Innovative learning in work teams: Analyzing cycles of knowledge creation in practice. In Y. Engeström, R. Miettinen, \& R. Punamäki (Eds.), Perspectives on activity theory (Learning in doing: social, cognitive and computational perspectives (pp. 377-404). Cambridge: Cambridge University Press. doi: 10.1017/CBO9780511812774.025. 
Engestrom, Y. (2000). Activity theory as a framework for analyzing and redesigning work. Ergonomics, 43(7), 960-974.

Engeström, Y. (2001). Expansive learning at work: Toward an activity theoretical reconceptualization. Journal of Education and Work, 14(1), 133-156.

Engeström, Y. (2007). Enriching the theory of expansive learning: Lessons from journeys toward co-configuration. Mind, Culture, and Activity, 14(1-2), 23-39.

Engeström, Y., Rantavuori, J., \& Kerosuo, H. (2013). Expansive learning in a library: Actions, cycles and deviations from instructional intentions. Vocations and Learning, 6(1), 81-106.

Engeström, Y., \& Sannino, A. (2010). Studies of expansive learning: Foundations, findings and future challenges. Educational Research Review, 5, 1-24 doi: 10.1016/j.edurev.2009.12.002.

Engeström, Y., \& Sannino, A. (2016). Expansive learning on the move: insights from ongoing research. Childhood and Learning: Journal for the Study of Education and Development, 39(3), 417-435.

Fernández Rodríguez, E., \& Martínez Rodríguez, J. B. (2018). Opening educational research to the plurality of contexts, agents and knowledge. In J. B. Martínez Rodríguez, \& E. Fernández Rodríguez (Eds.), Learning ecologies. Expanded education in multiple contexts. Madrid: Morata. Garrido Arroyo, M. C., Sosa Díaz, M. J., \& Arriazu Muñoz, R. (2018). Labs of change and expansive learning. Alternative education in childhood. In J. B. Martínez Rodríguez, \& E. Fernández Rodríguez (Eds.), Learning ecologies. expanded education in multiple contexts. Madrid: Morata. Glaser, B., \& Strauss, A. (1967). The discovery of grounded theory: strategies for qualitative research. New York: Aldine de Gruyter.

Haythornthwaite, C. (2015). Rethinking learning spaces: Networks, structures and possibilities for learning in the twenty-first century. Communication, Research and Practice, 1(4), 292-306. López Yáñez, J. (2009). Opening the black box. A systemic perspective on change in educational organizations. XXI. Journal of Education, 5, 139-155.

López, J., Altopiedi, M., Lavié, J. M., Sánchez, M., \& Murillo, P. (July 4-6, 2002). Towards a social ecology of educational organizations. Educational and community development in the Sierra Norte de Sevilla. [Conference presentation]. VII Interuniversity Congress of Organization of Educational Institutions. Spain: Saint Sebastian,

Leontíev, A. N. (1981). Problems of the Development of the Mind. Moscow: Progress.

Sepúlveda, G. (August 14, 2001). What is expansive learning? [Conference presentation]. National

Meeting of Education and Heritage, Spain: Santiago.

Stake, R. E. (1998). Research with case studies. Madrid: Morata.

Strauss, A., \& Corbin, J. (2002). Bases of qualitative research. Techniques and procedures to develop grounded theory. Colombia: University of Antioquia.

Vygotsky, L. S. (1978) Mind in society: the development of higher psychological processes. Cambridge: Harvard University Press.

Wenger, E. (2001). Communities of practice. Learning, meaning and identity. Barcelona: Paidós. Yin, R. K. (2009). Case Study Research: Design and methods. Thousand Oaks: SAGE Publications. 


\section{Annexes}

Annex 1

\section{Question Guide Protocol:}

1. How was the process of creating the center and where did the idea start?

2. What educational philosophy promotes and defends the center?

3. In what pedagogical aspects does your center differ from a public educational one?

4. How is the centre funded?

5. What is the method of enrollment? Are there any criteria which must be met in order to access the centre?

6. How are decisions made regarding the pedagogical model and didactic issues in the center? What advantages for learning does the methodology developed by the center have?

7. How is your classroom/center physically structured? Who makes the decisions regarding the structure of the center and the spaces?

8. How is work organized in the center and how are decisions made? Are there working commissions? Or people with administrative roles? Do you think there is a good organization?

9. What organizational difficulties have you encountered? How do you plan to solve organizational difficulties?

10. Do you participate in the center? Do you make decisions within the facility? Would you like to make decisions? Is it difficult for you to participate? Why?

11. Are family members involved in educational and organizational work? How do they participate?

12. In addition to the closest relatives, do other people attend the center to improve the educational quality of students? For example: grandparents, cousins, other professionals, etc.?

13. Do you encourage other parents to take their children to this center?

14. What is the plan for the future?

15. In general, what aspects can be improved at the center? 


\title{
Bendruomenès ekologija ir išplèstinis mokymasis. Besimokanti bendruomenè ugdymo transformacijai
}

\author{
María José Sosa Díaz ${ }^{1}$, María del Carmen Garrido Arroyo ${ }^{2}$ \\ Estremadūros universitetas, Pedagogų rengimo fakultetas, Edukologijos mokslų katedra, Universiteto alëja, ES-10003, \\ Kaseresas, Ispanija, mjosesosa@unex.es \\ 2 Estremadūros universitetas, Pedagogų rengimo fakultetas, Edukologijos mokslų katedra, Universiteto alejja, ES-10003, \\ Kaseresas, Ispanija, cargarri@unex.es
}

\section{Santrauka}

Išplèstinis mokymasis yra mokymosi modelis, kuris iš esmès apibrèžia, kaip mes suprantame mokymosi procesus, ir kuris leidžia analizuoti, kaip mokymasis vyksta švietimo bendruomenejje, kur jos narių dalyvavimas ir ryšiai yra būtini socialinei transformacijai.

Atsižvelgiant i šią koncepciją, kaip atspirties tašką, buvo sukurta tyrimo metodika, kuria siekiama užfiksuoti, išanalizuoti ir aprašyti, kaip išplèstinis mokymosi procesas gali vykti skirtingose veiklos sistemose, ir (arba) nustatyti kliūtis, sunkumus ir iššūkius bendruomeninejje praktikoje ir institucijose. Šiuo tikslu buvo taikoma kokybinė metodologija, atliekama atvejo analizè, analizei pasitelkiant praktikuojančią bendruomenę „Espacio Libre Candil“, kuri buvo sukurta kaip ,alternatyvi“ mokykla edukaciniam projektui.

Kaip pagrindiniai grupès mokymosi veiksmai duomenims rinkti buvo naudojami pusiau struktūruoti reikšmingų švietimo bendruomenès narių interviu, taip pat dviejų susirinkimų stebejjimas nedalyvaujant. Rezultatai atskleidè, kad mokytis galima grupejje, tai ịrodo bendruomenių kūrybinis pajègumas, kai suteikiama galimybė dalyvauti grupès organizavimo ir valdymo veikloje. Mokymosi matricos analizė leidžia sužinoti, kas, ką, kodèl ir kaip mokosi grupeje. Išanalizavus mokymosi ciklinị pobūdị, taip pat nustatyta kiekvieno mokymosi ciklo kartotinẻ kilpa. Išvados rodo, kad yra ir kitokių mokymosi formų, sukurtų iš patirties ir santykių ìvairiose kultūrinėse ekosistemose, kurias galima vadinti bendruomenès ekologija.

Esminiai žodžiai: išplèstinis mokymasis, mokymosi ekologija, bendruomenés ekologija, atveju analizé, kokybinis tyrimas, alternatyvus švietimas, mokymosi bendruomene. 